\title{
Studies on Variability, Heritability and Genetic Advance for Quantitative Characters in Finger millet [Eleusine coracana (L.) Gaertn] Germplasm
}

\author{
M. Mahanthesha ${ }^{1 *}$, M. Sujatha ${ }^{1}$, Ashok Kumar Meena ${ }^{1}$ and S.R. Pandravada ${ }^{2}$ \\ ${ }^{1}$ Department of Genetics and Plant Breeding, College of Agriculture, \\ Rajendranagar, ANGRAU, Hyderabad, India \\ ${ }^{2}$ Department of Economic Botany, National Bureau of Plant Genetic Resources, \\ Regional station, Hyderabad, India \\ *Corresponding author
}

\begin{tabular}{|c|c|}
\hline & A B S T R A C T \\
\hline & \multirow{7}{*}{$\begin{array}{l}\text { The analysis of variance revealed significant differences among genotypes for all } \\
\text { the characters. Studies of genetic variability revealed high phenotypic and } \\
\text { genotypic coefficients of variation, heritability and genetic advance as per cent of } \\
\text { mean for the traits viz., number of basal tillers per plant, no. of productive tillers } \\
\text { per plant, main ear width, grain yield per plant and grain yield per plot indicating } \\
\text { simple selection can be practiced for improvement of these characters. The } \\
\text { genotypic coefficient of variation for all the characters studied was lesser than the } \\
\text { phenotypic coefficient of variation indicating the effect of environment. High } \\
\text { GCV and PCV values were observed for grain yield per plot followed by grain } \\
\text { yield per plant, no. of basal tillers per plant, productive tillers per plant, main ear } \\
\text { width and finger length. High heritability coupled with high genetic advance as } \\
\text { per cent of mean was observed for plant height, number of basal tillers per plant, } \\
\text { no. of productive tillers per plant, main ear length, main ear width, finger length, } \\
\text { grain yield per plant and grain yield per plot. Thus, these traits are predominantly } \\
\text { under the control of additive gene action and hence these characters can be } \\
\text { imbroved bv selection. }\end{array}$} \\
\hline & \\
\hline & \\
\hline $\begin{array}{l}\text { Heritability, } \\
\text { Genetic advance. }\end{array}$ & \\
\hline Article Info & \\
\hline $\begin{array}{l}\text { Accepted: } \\
\text { 17 May } 2017 \\
\text { Available Online: } \\
\text { 10 June } 2017\end{array}$ & \\
\hline & \\
\hline
\end{tabular}

\section{Introduction}

Finger millet [Eleusine coracana (L.) Gaertn.] Also known as African millet or Ragi, it is a self pollinated tetraploid $(2 n=36)$ crop. It is the most important small millet cultivated in more than 25 countries in Africa and Asia. The major producers are Uganda, India, Nepal and China. India is the major producer in Asia. In India ragi is grown in an area of 2 million hectares with a production of 2.15 million tonnes, which accounts for 45 per cent of the world's cultivated area and 55 per cent of the world's production. Ragi is widely grown in the states of Karnataka, Tamil Nadu, Andhra Pradesh, Maharashtra, Orissa, Gujarat, Jharkhand, Uttar Pradesh, Madhya Pradesh and Uttarakhand (Ministry of Agriculture, 2012).

Finger millet is highly nutritious as its grain contains the high quality protein (7-10\%). It is 
the richest source of calcium $(344 \mathrm{mg} / 100 \mathrm{~g})$, iron $(3.9 \mathrm{mg} / 100 \mathrm{~g})$ and other minerals. It is also rich in phosphorus $(283 \mathrm{mg} / 100 \mathrm{~g})$ and potassium $(408 \mathrm{mg} / 100 \mathrm{~g})$. It is highly valued as a reserve food in the times of famine. Despite all these merits, this crop has been neglected from the main stream of crop improvement programme. One of the means to boost its production and productivity is to enhance utilization of finger millet.

Exploitation of genetic variability existing in the working germplasm is the first principle in the improvement of any crop. Analysis and utilization of available genetic diversity is a short-term strategy for developing improved cultivars for meeting immediate requirement of the farmers and the end users. The finger millet crop has a wide range of variation for its character.

\section{Materials and Methods}

The experimental materials consisting forty eight germplasm lines were sown in a randomized block design with three replications, during kharif 2013 at National Bureau of Plant Genetic Resources, Regional station, Rajendranagar, Hyderabad. Adopted a spacing of $22.5 \mathrm{~cm}$ between rows and $10 \mathrm{~cm}$ between plants respectively, at recommended package of practices werefollowed to raise good and healthy crop stand. Trails were laid out in a Randomized Block Design with three replications. Data were collected on eleven yield and yield contributing characters viz., plant height, no. of basal tillers per plant, no. of leaves on the main tiller, productive tiller per plant, main ear length, main ear width, finger length, finger width, total no. of fingers on the main ear, grain yield per plant and grain yield per plot (Table 2).

The mean of three plants was subjected to statistical analysis. The data for different characters were statistically analyzedfor significance by using analysis of variance technique described by Panse and Sukhatme (1985). The adopted design was Randomized Block Design (RBD) replicated thrice. The significance of mean sum of squares for each character was tested against the corresponding error degrees of freedom using ' $F$ ' Test (Fisher and Yates, 1967). The components of variances were used to estimate genetic parameters like phenotypic and genotypic coefficient of variation (PCV and GCV) as per the formulae given by Burton and DeVane (1953). Heritability in the broad sense was calculated according to the formula given by Allard (1960) and expressed in percentage. Genetic advance was estimated by using Burton (1953) formula.Statistical analysis was done by using WINDOSTAT program.

\section{Results and Discussion}

The analysis of variance revealed significant differences among genotypes for all the characters. Studies of genetic variability revealed high phenotypic and genotypic coefficients of variation, heritability and genetic advance as percent of mean for the traits viz., number of basal tillers per plant, no. of productive tillers per plant, main ear width, grain yield per plant and grain yield per plot indicating simple selection can be practiced for improvement of these characters (Table 1).

Improvement of economic characters like yield through selection is conditioned by the nature and magnitude of variability existing in such populations. However, the phenotypic expression of complex character like yield is a combination of genotype, environment and their interaction. This indicates the need for partition of overall variability into heritable and non-heritable components with the help of appropriate statistical techniques.

Possibility of achieving improvement in any crop plants depends heavily on the magnitude of genetic variability. Phenotypic variability 
expressed by a genotype or a group of genotypes in any species can be partitioned into genotypic and environmental components. The genotypic component being the heritable part of the total variability, its magnitude for yield and its component characters influences the selection strategies to be adopted by the breeders.

Coefficients of variation studies indicated that the estimates of PCV were slightly higher than the corresponding GCV estimates for all the characters, indicating that the characters were less influenced by the environment. Therefore, selection on the basis of phenotype alone can be effective for the improvement of these traits (Lal et al., 1996).

Moderate heritability with high genetic advance was recorded for total no. of fingers on the main ear and moderate heritability with moderate genetic advance was recorded for total no. of leaves on main tiller and finger width. These traits appear to be under the control of both additive and non-additive gene actions (Jain and Yadava 1999).

Phenotypic variances were higher than genotypic variances. Phenotypic (PCV) and genotypic coefficients of variation (GCV) were high for number of tillers, number of effective tillers, grain yield per plant, straw yield per plant and weight of grains of main earhead (Bendale et al., 2002).

In the present investigation, high heritability coupled with high genetic advance as per cent of mean was observed for plant height, number of basal tillers per plant, no. of productive tillers per plant, main ear length, main ear width, finger length, grain yield per plant and grain yield per plot Thus, these traits are predominantly under the control of additive gene action and hence these characters can be improved by selection (Mohan Prem Anand et al., 2005). The varietal improvement for grain yield is mainly dependent upon the extent of genetic variability present in the population. High genotypic and phenotypic coefficient of variation was observed for number of productive tillers per plant, number of fingers per ear and total dry matter production. Number of productive tillers per plant, number of fingers per ear, test weight, total dry matter production and harvest index possessed high heritability coupled with high estimates of genetic advance (John et al., 2006).

Table.1 Pooled analysis of Variance for yield and yield contributing traits in finger millet

\begin{tabular}{|c|c|c|c|c|c|c|c|c|c|c|c|}
\hline $\begin{array}{c}\text { Source of } \\
\text { Variation }\end{array}$ & Df & $\begin{array}{c}\text { Plant } \\
\text { height }\end{array}$ & $\begin{array}{c}\text { No. of } \\
\text { basal } \\
\text { tillers } \\
\text { per } \\
\text { plant }\end{array}$ & $\begin{array}{c}\text { No. of } \\
\text { leave } \\
\text { on the } \\
\text { main } \\
\text { tiller }\end{array}$ & $\begin{array}{c}\text { Productive } \\
\text { tillers per } \\
\text { plant }\end{array}$ & $\begin{array}{c}\text { Main } \\
\text { ear } \\
\text { length }\end{array}$ & $\begin{array}{c}\text { Main } \\
\text { ear } \\
\text { width }\end{array}$ & $\begin{array}{c}\text { Finger } \\
\text { length }\end{array}$ & $\begin{array}{c}\text { Finger } \\
\text { width }\end{array}$ & $\begin{array}{c}\text { Total } \\
\text { fingers } \\
\text { on the } \\
\text { main } \\
\text { ear }\end{array}$ \\
\hline Replications & 2 & 46.58 & 0.46 & 0.07 & 0.083 & 1.785 & 0.10 & 0.75 & $0.18^{* *}$ & 0.19 & 1.86 \\
yield per \\
plant \\
Genotypes
\end{tabular}

(** Significant at 1 per cent level) 
Table.2 Experimental material of 48 genotypes of finger millet

\begin{tabular}{|c|c|c|c|c|c|}
\hline SL. No. & Genotypes & Source & SL. No & Genotypes & Source \\
\hline 1 & 13426 & NBPGR Regional Research Station & 25 & 13651 & NBPGR Regional Research Station \\
\hline 2 & 13433 & NBPGR Regional Research Station & 26 & 13652 & NBPGR Regional Research Station \\
\hline 3 & 13434 & NBPGR Regional Research Station & 27 & 13660 & NBPGR Regional Research Station \\
\hline 4 & 13484 & NBPGR Regional Research Station & 28 & 13661 & NBPGR Regional Research Station \\
\hline 5 & 13486 & NBPGR Regional Research Station & 29 & 13665 & NBPGR Regional Research Station \\
\hline 6 & 13487 & NBPGR Regional Research Station & 30 & 13672 & NBPGR Regional Research Station \\
\hline 7 & 13489-1 & NBPGR Regional Research Station & 31 & 13673 & NBPGR Regional Research Station \\
\hline 8 & 13492 & NBPGR Regional Research Station & 32 & 13674 & NBPGR Regional Research Station \\
\hline 9 & 13502 & NBPGR Regional Research Station & 33 & 13675 & NBPGR Regional Research Station \\
\hline 10 & 13517 & NBPGR Regional Research Station & 34 & 13676 & NBPGR Regional Research Station \\
\hline 11 & 13523 & NBPGR Regional Research Station & 35 & 13677 & NBPGR Regional Research Station \\
\hline 12 & 13528 & NBPGR Regional Research Station & 36 & 13678 & NBPGR Regional Research Station \\
\hline 13 & 13539 & NBPGR Regional Research Station & 37 & 13689 & NBPGR Regional Research Station \\
\hline 14 & 13542 & NBPGR Regional Research Station & 38 & 13690 & NBPGR Regional Research Station \\
\hline 15 & 13555 & NBPGR Regional Research Station & 39 & 13691 & NBPGR Regional Research Station \\
\hline 16 & 13565 & NBPGR Regional Research Station & 40 & 13700 & NBPGR Regional Research Station \\
\hline 17 & 13567 & NBPGR Regional Research Station & 41 & 13710 & NBPGR Regional Research Station \\
\hline 18 & 13568 & NBPGR Regional Research Station & 42 & 13712 & NBPGR Regional Research Station \\
\hline 19 & 13569 & NBPGR Regional Research Station & 43 & 13713 & NBPGR Regional Research Station \\
\hline 20 & 13570 & NBPGR Regional Research Station & 44 & GPU-45 & NBPGR Regional Research Station \\
\hline 21 & 13571 & NBPGR Regional Research Station & 45 & GPU-67 & NBPGR Regional Research Station \\
\hline 22 & 13631 & NBPGR Regional Research Station & 46 & PR-202 & NBPGR Regional Research Station \\
\hline 23 & 13632 & NBPGR Regional Research Station & 47 & VL-149 & NBPGR Regional Research Station \\
\hline 24 & 13650 & NBPGR Regional Research Station & 48 & VR-708 & NBPGR Regional Research Station \\
\hline
\end{tabular}

Table.3 Genetic parameters for yield and yield contributing characters in finger millet

\begin{tabular}{|l|c|c|c|c|c|}
\hline Character & GCV (\%) & PCV (\%) & $\begin{array}{l}\text { Heritability } \\
(\%) \\
(\mathrm{bs})\end{array}$ & $\begin{array}{l}\text { Genetic } \\
\text { Advance }\end{array}$ & $\begin{array}{l}\text { Genetic } \\
\text { Advance as per } \\
\text { cent of mean } \\
(5 \%)\end{array}$ \\
\hline Plant height & 15.43 & 19.84 & 60 & 17.09 & 24.71 \\
\hline No. ofbasal tillers per plant & 25.17 & 28.01 & 80 & 4.99 & 46.60 \\
\hline No. of leaves on the main tiller & 10.82 & 16.80 & 41 & 1.18 & 14.35 \\
\hline Productive tillers per plant & 28.40 & 31.51 & 81 & 5.42 & 52.72 \\
\hline Main ear length & 19.86 & 24.63 & 65 & 2.64 & 32.98 \\
\hline Main ear width & 37.14 & 39.56 & 88 & 5.81 & 71.85 \\
\hline Finger length & 23.26 & 27 & 74 & 2.71 & 41.29 \\
\hline Finger width & 6.48 & 8.89 & 53 & 0.09 & 9.73 \\
\hline Total fingers on the main ear & 16.38 & 22 & 55 & 2.21 & 25.14 \\
\hline Grain yield per plant & 54.37 & 55.18 & 97 & 41.59 & 110.38 \\
\hline Grain yield per plot & 54.77 & 55.64 & 96 & 1274.62 & 111.05 \\
\hline
\end{tabular}

Low GCV and PCV for plant height and days to fifty per cent of flowering whereas moderate values for productive tillers, grain yield per plant and finger length coupled with 
high heritability and genetic advance as per cent of mean (Sumathi et al., 2007).

Genotypic coefficient of variation (GCV) along with heritable estimates would provide a better picture of the amount of genetic advance to be expected by phenotypic selection (Burton, 1953). It is suggested that genetic gain should be considered in conjunction with heritability estimates (Johnson et al., 1955). Heritability estimates along with genetic advance are normally more helpful in predicting the gain under selection than heritability estimates alone (Table 3 ).

In conclusion, the material chosen differed in their genotypic make up as evidenced by the significant differences among them in respect of all the quantitative characters studied. Phenotypic coefficient of variation estimate was slightly higher than the genotypic coefficient of variation for all the traits, indicating low environmental influence on the expression of all the traits.

\section{References}

Allard, R.W. 1960. Principles of plant breeding. John Willey and Sons Inc. New York. pp. 485.

Bendale, V.W., Bhave, S.G. and Pethe, U.B. 2002. Genetic variability, correlation and path analysis in finger millet (Eleusine coracana Gaertn.). J. Soils Crops, 12: 187191.

Burton, G.W. 1953. Quantitative inheritance in grasses. Proceeding on $6^{\text {th }}$ International Grass Land Congress J., 1: 277-283.

Burton, G.W. and De vane, E.H. 1952. Estimating heritability in tall Fescue
(Festuca arundinacea) from replicated clonal material. Agronomy J., 45: 478-481.

Fisher, R.A. and Yates. 1967. Statistical Tables for Biological Agricultural and Medical Research Olivar and Boyd, Edington.

Jain, A.K and Yadava, H.S. 1999. Correlated response for blast resistance in finger millet. Crop Res., 17: 403-407.

John, K. 2006. Variability and Correlation Studies in Quantitative traits of Finger Millet (Eleusine coracana Gaertn). Agri. Sci. Digest, 26: 166-169.

Johnson, H.W., Robinson, H.F. and Comstock, R.E. 1955. Estimates of genetic and environmental variability in soybean. Agron. J., 47: 314-318.

Lal, C., Dawa, T., Plaha, P. and Sharma, S.K. 1996. Studies on genetic variability and component analysis in ragi (Eleusine coracana Gaertn), Indian J. Genet., 56(2): 162-168.

Ministry of Agriculture., http: //www.indiastat.com/agriculture/2/stats/asp. 2012.

Mohan Prem Anand, M., Gururaja Rao, M.R., Kulkarni, R.S. and Ravishankar, C.R. 2005. An assessment of Variability Produced in F2 Generation of Three Crosses of Finger millet (Eleusine coracana Gaertn), Mysore J. Agri. Sci., 39(4): 553-556.

Panse, V.G. and Sukhatme, P.V. 1985. Statistical Methods for Agricultural Workers. Indian Council of Agricultural Research, New Delhi.

Sumathi, P., John Joel and Muralidharan, V. 2007. Genetic variability in the hybrids of finger millet (E. corcana (L.) Gaertn.). $J$. Crop Res., 33(1, 2 and 3): 192-194.

\section{How to cite this article:}

Mahanthesha, M., M. Sujatha, Ashok Kumar Meena and Pandravada, S.R. 2017. Studies on Variability, Heritability and Genetic Advance for Quantitative Characters in Finger millet [Eleusine coracana (L.) Gaertn] germplasm. Int.J.Curr.Microbiol.App.Sci. 6(6): 970-974. doi: https://doi.org/10.20546/ijcmas.2017.606.113 